\title{
A new method of gall mite management: application of artificial defoliation to control Aceria pallida
}

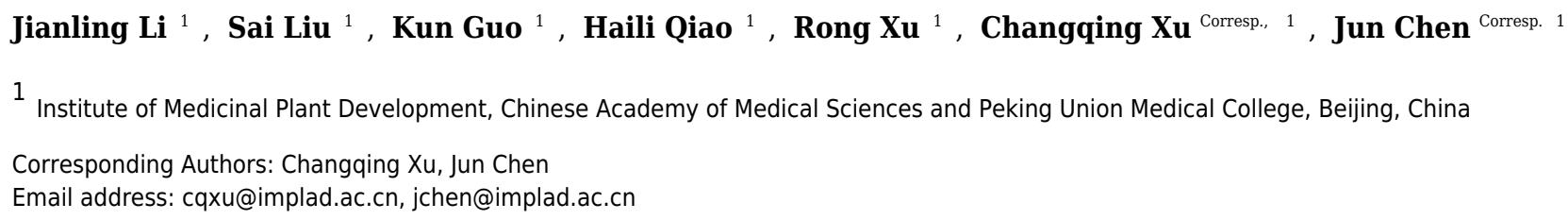

Artificial defoliant is widely applied to cotton to facilitate mechanical harvesting and successfully controls leaf diseases by blocking pathogen epidemical cycles; however, this technique is rarely used to control herbivores. Because many eriophyoid mites live and reproduce in galls, the control of these mites by pesticides is usually limited. However, the abscission of galled foliage is lethal to tiny mites with low mobility. Therefore, artificial defoliation should be effective in controlling gall mites. Here, the effects of defoliant on the control of the goji berry Lycium barbarum L. gall mite Aceria pallida Keifer were compared with those of pesticides under field conditions over 3 years. Our results showed that artificial defoliation enabled almost complete defoliation and timely refoliation. A. pallida galls fell off with the defoliation, and then regenerated foliage escaped from mite attack. After defoliant application, the densities of mite galls decreased by $84.1 \%, 80.3 \%$ and 80.3\% compared with those found in the pesticide (undefoliated) treatment in 2012, 2013 and 2014, respectively. Artificial defoliation achieved much better control of gall mites than pesticides. 


\section{A new method of gall mite management: application of artificial defoliation to control}

\section{Aceria pallida}

3

4 Jianling Li, Sai Liu, Kun Guo, Haili Qiao, Rong Xu, Changqing Xu and Jun Chen

5

6 Institute of Medicinal Plant Development, Chinese Academy of Medical Sciences and Peking

7 Union Medical College, Beijing, China

8

9 Corresponding authors:

10 Changqing $\mathrm{Xu}$, Jun Chen

11 No. 151 Malianwa North Road, Haidian District, Beijing, 100193, China

12 Email address: cqxu@implad.ac.cn, jchen@implad.ac.cn 


\section{ABSTRACT}

15 Artificial defoliant is widely applied to cotton to facilitate mechanical harvesting and

16 successfully controls leaf diseases by blocking pathogen epidemical cycles; however, this

17 technique is rarely used to control herbivores. Because many eriophyoid mites live and

18 reproduce in galls, the control of these mites by pesticides is usually limited. However, the

19 abscission of galled foliage is lethal to tiny mites with low mobility. Therefore, artificial

20 defoliation should be effective in controlling gall mites. Here, the effects of defoliant on the

21 control of the goji berry Lycium barbarum L. gall mite Aceria pallida Keifer were compared

22 with those of pesticides under field conditions over 3 years. Our results showed that artificial

23 defoliation enabled almost complete defoliation and timely refoliation. A. pallida galls fell off

24 with the defoliation, and then regenerated foliage escaped from mite attack. After defoliant

25 application, the densities of mite galls decreased by $84.1 \%, 80.3 \%$ and $80.3 \%$ compared with

26 those found in the pesticide (undefoliated) treatment in 2012, 2013 and 2014, respectively.

27 Artificial defoliation achieved much better control of gall mites than pesticides.

28 Keywords: pest management; eriophyoid mite; gall-maker; defoliant; Lycium barbarum 


\section{INTRODUCTION}

31 Phytophagous mites cause serious direct damage to economically important plants by sucking

32 plant sap (Van Leeuwen et al., 2010; Marcic, 2012) and lead to indirect damage as vectors of

33 plant pathogens (Andret-Link \& Fuchs, 2005; de Lillo et al., 2018). Chemical control is usually

34 efficient in suppressing the damage caused by free-living mites, which live on the surface of

35 plant tissues (Marcic, 2012; Van Leeuwen et al., 2014). However, some species, especially

36 eriophyoid mites, induce galls on plant tissues as refuges in which these mites spend most of

37 their life cycle; thus, pesticide control of such species is always limited (Childers, Easterbrook \&

38 Solomon, 1996; Navia et al., 2010; Van Leeuwen et al., 2010).

39 For eriophyoid mites with tiny bodies (adult body length averaging approximately $200 \mu \mathrm{m}$ )

40 (Lindquist, 1996), passive long-distance dispersal mainly depends on wind, which is inefficient

41 and poses a high risk for host-specific mites to land on suitable plants (Lindquist \& Oldfield,

42 1996; Michalska et al., 2010). Active dispersal by slow walking only occurs over relatively short

43 distances, mainly within the same plant or between plants touching each other (Michalska et al.,

44 2010). Leaf abscission takes the mites too far to return to the host plant by ambulation (Sabelis \&

45 Bruin, 1996); thus, the defoliation of gall foliage is fatal to gall mites. In practice, farmers often

46 prune the infested leaves or branches to decrease gall mite damage in addition to applying

47 pesticides (Oldfield \& Proeseler, 1996; Duso et al., 2010). Although pruning galled tissues is

48 always considered effective in controlling gall mites, this method is inefficient and costly. In this

49 study, artificial defoliation is proposed as a feasible and effective method of decreasing the

50 damage caused by gall mites.

51 Artificial defoliation is widely applied to cotton to facilitate mechanical harvesting and

52 often used to simulate defoliation by herbivory to study plant responses (Kulman, 1971; Lee \& 
53 Morton, 2013; Quentin et al., 2010). Many studies have been published about the effects of

54 artificial defoliation on plant physiology, yield and quality (Reichenbacker, Schultz \& Hart,

55 1996; Faircloth et al., 2004; Eyles et al., 2013; Mo et al., 2018). Additionally, artificial

56 defoliation has been shown to be effective in preventing leaf disease caused by Colletotrichum

57 gloeosporioides Penz. and Oidium heveae Steinm. in Hevea rubber trees by accelerating

58 defoliation and refoliation to disrupt pathogen epidemical cycles (Rao, 1971; Guyot, et al.,

59 2001). Few studies have considered the control effects of artificial defoliation on phytophagous

60 pests, especially gall mites, which are difficult to control with pesticides. Knowledge of how

61 artificial defoliation affects gall mites may provide a new approach for controlling these kinds of

62 pests.

63 In this study, the eriophyoid mite Aceria pallida Keifer (Eriophyoidea) and its host goji

64 berry bush Lycium barbarum L. (Solanaceae) were used as a model system. The gall mite is a

65 predominant pest of the goji berry bush, which is among the most widely cultivated medicinal

66 herbs in China (Xu et al., 2014). The mite mainly feeds on foliage, leading to tissue deformation

67 and gall formation (Fig. 1), and decreases in plant production. Because gall mites reproduce and

68 live in galls, the period to effectively control these mites is usually confined to the time when

69 they are emigrating from galls to invade other tissues (Childers, Easterbrook \& Solomon, 1996;

70 Hrudová \& Šafránková, 2017). Eriophyoid mites reproduce by parthenogenesis, their generations

71 overlap considerably, and hundreds of mites of different stages live in each gall (Oldfield \&

72 Michalska, 1996; Michalska et al., 2010). Pesticides are frequently utilized to suppress mite

73 population growth to ensure the protection of these bushes; however, pesticide abuse not only

74 increases mite resistance but also causes pollution to the goji berry fruit and environment (Xu et

75 al., 2014). As pesticide contamination is currently a bottleneck in the export of goji berry in 
76 China, safe and effective methods of controlling gall mites are urgently needed in production

77 systems to decrease the use of pesticides (Xu et al., 2014; Yao et al., 2018).

78 Similar to many other deciduous trees, goji berry bushes undergo defoliation twice per year.

79 The first defoliation occurs after harvest in July and during the growing season, and the second

80 defoliation occurs in November to allow for overwintering survival (Li et al., 2018). Defoliation

81 in July is partial and prolonged and proceeds simultaneously with refoliation. Adults of $A$.

82 pallida have sufficient time to emigrate from galled foliage to regenerated foliage. Consequently,

83 the damage caused by the gall mite reappears in autumn and causes serious damage to

84 production. Moreover, the large overwintering population increases the difficulty of controlling

85 the mite in the next year. In this study, it is proposed that the renewal of foliage period in July

86 would be an appropriate time to apply artificial defoliation to control A. pallida. Here, the control

87 effect of a defoliant on A. pallida was compared with that of pesticides under field conditions

88 after harvest in July throughout a period of 3 years.

892 MATERIALS AND METHODS

$90 \quad 2.1$ Study site

91 The study was conducted in an experimental site of $2520 \mathrm{~m}^{2}$ (28 m width, $90 \mathrm{~m}$ length), located

92 in Zhongning $\left(37^{\circ} 29^{\prime} \mathrm{N}\right.$ and $\left.105^{\circ} 42^{\prime} \mathrm{E}\right)$, Ningxia Hui Autonomous Region, China, throughout 3

93 years $(2012,2013$ and 2014) from July to November. The site was planted with 840 bushes (14

94 columns and 60 rows) with a $2 \mathrm{~m}$ inter-row spacing and $1.5 \mathrm{~m}$ intra-row spacing in 2001 . The

95 crown diameter (approximately $1.4 \mathrm{~m}$ ) and height (approximately $1.5 \mathrm{~m}$ ) of these bushes were

96 similar. 


\section{$97 \quad 2.2$ Experimental design}

98 The experiments with defoliant and pesticide (undefoliated) treatments were conducted during

99 the self-renewal of foliage period in July. Prior to the study, the experimental site was treated

100 with pesticides according to local pesticide usage. Based on the methods outlined by Lawal

101 (2014), the experimental site was equally divided into ten plots, with each plot consisting of 84

102 bushes ( 7 columns and 12 rows); and the two treatments of 5 plots each were arranged in a

103 completely randomized design each year. All bushes of a plot received the same treatment, and

104 the outside rows (34 bushes) were considered buffer areas and were not sampled. One defoliant

105 and 8 pesticides were utilized to manage the gall mite, and they were applied by a mechanical

106 sprayer (SP-50, 21-40 kg/cm², Shanghai Panda Machinery Co., Ltd, China) (Table 1). Defoliant

107 without pesticide was sprayed only one time in each defoliant plot each year. To compare the

108 control effect of the defoliant and pesticides (including chemical, mineral and biological

109 pesticides) on the gall mite, pesticides were sprayed 2, 4 and 3 times based on the local use of

110 chemical pesticide in 2012, 2013 and 2014, respectively (Table 2).

111 To study the effects of defoliant and pesticides on defoliation and refoliation, 2 out of 50

112 bushes were chosen randomly in different columns and rows in each plot in 2012 . Then, 4

113 branches per bush at approximately $20 \mathrm{~cm}$ long from the tip (approximately 30 leaves per branch

114 before defoliant application) at different orientations were tagged to record the number of old

115 foliage and regenerated foliage at $0,1,3,7$ and 13 days after defoliant application. To study the

116 effects of the defoliant on the dynamics of galls, 2 bushes and 4 branches per bush were chosen

117 to record the number of $A$. pallida galls twice per month using the abovementioned sampling

118 methodology from 2012 to 2014. 


\section{$119 \quad 2.3$ Statistical analysis}

120 The statistical software SPSS version 21.0 (IBM, Chicago, IL, USA) was used for the statistical

121 analyses. Significant differences in the density of leaves at different orientations were analyzed

122 using a one-way ANOVA followed by Turkey's HSD tests. Significant differences in the density

123 of leaves in different treatments were analyzed using independent sample $t$-tests. Significant

124 differences in the dynamics of galls were analyzed using a repeated-measures ANOVA.

\section{RESULTS}

\section{3.1 Effects of defoliant and pesticides on the defoliation and refoliation of foliage}

127 Before defoliant application in 2012, the densities of foliage at different orientations were not

128 significantly different $\left(F_{7,32}=1.234, P=0.313\right)$ (Fig. S1). After defoliant application, the foliage

129 fell off much more rapidly and completely and more leaves sprouted in time (Table 3). Three

130 days after defoliant application, more than $90 \%(94.4 \%)$ of the old leaves had fallen off in the

131 defoliant plots; $10.5 \%$ had fallen off in the pesticide plots $\left(t_{4}=-32.895, P<0.001\right)$; and none of

132 the foliage regenerated in the two treatments. Seven days after defoliant application, almost all

133 the old foliage (97.1\%) had dropped and $5.3 \pm 2.71$ new foliage per branch had sprouted out.

134 However, only $25.4 \%$ of the old foliage had defoliated, and no foliage germinated in the

135 pesticide plots. On the 13th day after defoliant application, less than half $(41.6 \%)$ of the old

136 foliage had dropped and $2.1 \pm 1.44$ new foliage per branch emerged in the pesticide plots. Thus,

137 refoliation and defoliation proceeded simultaneously in the pesticide plots. The number of

138 regenerated leaves in the defoliant treatment was up to 35 times greater than that in the pesticide

139 treatment $\left(t_{4}=15.223, P<0.001\right)$. 
$140 \quad 3.2$ Effects of defoliant and pesticides on the density of galls

141 In the pesticide treatment, different kind, combination and application date of pesticides did not

142 effectively prevent the gall mite infestation over 3 years (Fig. 2A, B and C). The dynamics of

143 galls followed similar patterns. In July, the number of galls fluctuated slowly with the prolonged

144 renewal of foliage. With the refoliation in August, adult mites migrated from old to young

145 foliage and the gall number increased rapidly. The density of galls reached its peak in September

146 (2012: $22.14 \pm 4.66 ; 2013: 16.2 \pm 7.31)$ (Fig. 2A, B) or October (2014: $21.3 \pm 7.37$ ) (Fig.2C).

147 After that, mite galls fell off with the defoliation with the onset of winter. Adult mites migrated

148 from galls to their hibernation sites to ensure overwintering survival (Liu et al., 2016).

149 However, in the defoliant treatment, more than $90 \%$ of mite galls fell off within 11 days

150 after defoliant application over the course of 2012, 2013 and 2014 (Fig. 2A, B and C). Because

151 most galls had defoliated with the abscission of foliage (Table 3), few mites survived and caused

152 serious damage to plants. The fluctuation of galls was stable at a low density (Fig. 2A, B and C).

153 Throughout the investigation period, the mean densities of galls in the defoliant plots were

154 decreased by $84.1 \%$ (Fig. 2D), 80.3\% (Fig. 2E) and $80.3 \%$ (Fig. 2F) compared with those in the

155 pesticide plots in $2012\left(F_{1,4}=43.917, P<0.001\right), 2013\left(F_{1,4}=19.969, P=0.002\right)$ and $2014\left(F_{1,4}\right.$

$156=14.673, P=0.005)$ (Table 4), respectively. Artificial defoliation achieved better control effects

157 on the gall mite than pesticides by blocking nutrient supply.

\section{DISCUSSION}

159 Our results showed that increasing the frequency of chemical pesticides could not effectively

160 prevent gall mite infestation and high doses of natural pesticides did not achieve better control of

161 the mite than chemical pesticides and defoliant, although natural pesticides are often considered 
162 to be environmentally friendly and easily degradable (Copping \& Menn, 2000). The study

163 demonstrated that artificial defoliation, a new management method for controlling gall mites,

164 was much more effective than chemical and natural pesticides in preventing eriophyoid mites.

165 The results showed that artificial defoliation facilitated the abscission of old foliage and

166 stimulated timely refoliation. Galls caused by $A$. pallida fell off with the defoliation of galled

167 foliage, which was lethal to the tiny mites (Sabelis \& Bruin, 1996). When new foliage emerged,

168 almost all the old foliage with galls had been defoliated, and the residual number of gall mites on

169 bushes was too low to cause serious damage. However, defoliation and refoliation proceeded

170 partially and slowly without the defoliant. Adult $A$. pallida had sufficient time to emigrate from

171 old foliage to new sprouting foliage. Since galls provide shelter to mites and systemic pesticides

172 are lacking, chemical control programmes against eriophyoid gall mites are always limited

173 (Childers, Easterbrook \& Solomon, 1996; Van Leeuwen et al., 2010, 2014; de Lillo et al., 2018).

174 Neither chemical pesticides nor natural pesticides could effectively prevent the gall mite

175 infestation.

176 In contrast with other herbivorous mites that hibernate on host plants (Krantz \& Lindquist,

177 1979; Michalska et al., 2010; Walter \& Proctor, 2013), A. pallida is a phoront that is obligately

178 phoretic on the psyllid Bactericera gobica for survival in the winter (Liu et al., 2016; Li et al.,

179 2018). Although our results confirmed that artificial defoliation was effective in controlling the

180 gall mite, the effect on the psyllid was unknown. Because the psyllid feeds and breeds

181 exclusively on foliage (Li et al., 2018), the defoliation and desiccation of foliage should be

182 effective in the control of psyllid eggs and their inactive nymphs by blocking the insect's nutrient

183 supply. However, the generations of these pests overlap considerably, and adults with wings may

184 have migrated from the defoliated plots to other areas where food is available. Therefore, the 
185 effect of artificial defoliation on the control of pests with high mobility will always be limited. A

186 combination of defoliant and pesticides should be more effective than defoliant alone in

187 controlling these foliage pests and needs to be studied further.

188 Plant galls are abnormal vegetative growths in plant tissue, and they are most often

189 observed on foliage (approximately 65\%) and mainly induced by insects and mites (insects +

190 mites: approximately 70\%) (Mani, 1964; Abrahamson \& Weis, 1987). Although gall makers

191 rarely cause destructive damage to host plant growth (Sabelis \& Bruin, 1996; Stone \&

192 Schönrogge, 2003), some of them cause serious damage to economic plant production. For

193 example, the gall wasp Dryocosmus kuriphilus Yasumatsu could reduce the yield of Castanea

194 sativa Mill. by as much as 80\% (Battisti et al., 2014); the gall mite Aceria rhodiolae (Canestrini)

195 could decrease the medicinal quality (salidroside) of Rhodiola rosea L. by over 50\% (Beaulieu et

196 al., 2016). Gall-maker larvae acquire nutrition and shelter from plant galls to complete their

197 development (Price, Fernandes \& Waring, 1987; Stone \& Schönrogge, 2003); therefore, the

198 defoliation and desiccation of plant galls is deadly to these arthropod herbivores. Because

199 defoliants (tribufos, thidiazuron, ethephon, etc.) can facilitate timely defoliation, we suggest that

200 defoliant application may be effective in the control of other foliage gall-forming pests and not

201 merely goji berry gall mite, by blocking nutrient supply.

202 Our results showed that defoliant application enabled not only defoliation of goji berry

203 bushes but also quick refoliation. Previous publications have demonstrated that refoliation as a

204 defoliation-induced response of trees represents compensatory regrowth by depleting stored plant

205 reserves (Kosola et al., 2001; Lasseur et al., 2007; Wiley et al., 2013; Erbilgin et al., 2014;

206 Nakajima, 2018). Severe defoliation commonly has negative effects on the growth and

207 reproduction of trees. Reichenbacker et al. (1996) reported that the height, diameter and biomass 
208 of Populus clones decreased significantly with increasing defoliation. Jetton and Robison (2014)

209 documented that severe defoliation caused significant reductions in sweetgum Liquidambar

210 styraciflua L. stem growth and biomass accumulation. Similarly, Milbrath (2008) found that

211 increasing frequencies of severe defoliation caused greater reductions in biomass and seed

212 production of Vincetoxicum rossicum (Kleopow) and V. nigrum (L.). These detrimental

213 influences induced by defoliation can be alleviated by supplemental nutrients. For example, $\mathrm{N}$

214 fertilization can reverse the negative influence of defoliation on Populus $\times$ canadensi cv Eugeneii

215 diameter growth (Kosola et al., 2001), and N, P, K fertilizer can alleviate the reductions of $P$.

216 tremuloides (Mich.) biomass and leaf non-structural carbohydrate concentrations under repeated

217 defoliation (Erbilgin et al., 2014). However, in some cases, artificial defoliation is favourable to

218 the growth of trees. According to the report by Guyot et al. (2001), artificial defoliation increased

219 rubber production of $H$. brasiliensis (Willd. ex A. Juss.) by blocking leaf fall disease epidemical

220 cycles. Although our results showed that artificial defoliation was effective in controlling gall

221 mites and more regrowth leaves were quickly generated following defoliation, the plants not only

222 lost their photosynthetic capacity during defoliation but also the resources, most notably

223 nitrogen, contained in the leaves (Aerts, 1996; Eckstein, Karlsson \& Weih, 1998; Kosola et al.,

224 2001). Therefore, such a severe method might be detrimental to the growth of goji berry bushes

225 over a period of years. Further research is required to reveal the potential long-term effects of

226 artificial defoliation on the growth and production of goji berry bushes and promote quick

227 restoration.

2285 CONCLUSIONS

229 Artificial defoliation as a method of controlling gall mites was assessed for the first time. The 
230 results in the present study showed that artificial defoliation was particularly effective in

231 preventing the goji berry gall mite $A$. pallida infestation by facilitating leaf abscission to block

232 nutrient supply. The method of controlling gall-forming pests also reduces the risk of product

233 and environmental contamination by decreasing the use of pesticides.

\section{ACKNOWLEDGEMENTS}

235 The authors acknowledge the goji berry grower Mr. Jun Mao and the undergraduate student Jun

236 Yang for their kind help. 


\section{REFERENCES}

238 Abrahamson W, Weis A. 1987. Nutritional ecology of arthropod gall makers. In Slansky F,

239 Rodriquez JG, eds. Nutritional ecology of insects, mites, spiders, and related invertebrates.

$240 \quad$ New York: Wiley, 235-258.

241 Aerts R. 1996. Nutrient resorption from senescing leaves of perennials: are there general

242 patterns? Journal of Ecology 84:597-608 DOI: 10.2307/2261481.

243 Andret-Link P, Fuchs M. 2005. Transmission specificity of plant viruses by vectors. Journal of

$244 \quad$ Plant Pathology 87:153-165 DOI: 10.4454/jpp.v87i3.913.

245 Battisti A, Benvegnù I, Colombari F, Haack RA. 2014. Invasion by the chestnut gall wasp in

246 Italy causes significant yield loss in Castanea sativa nut production. Agricultural and Forest

247 Entomology 16:75-79 DOI: 10.1111/afe.12036.

248 Beaulieu F, Cuerrier A, Filion VJ, Saleem A, Arnason JT. 2016. A gall mite, Aceria rhodiolae

249 (Acari: Eriophyidae), altering the phytochemistry of a medicinal plant, Rhodiola rosea

250 (Crassulaceae), in the Canadian Arctic. Journal of Natural History 50:1237-1263 DOI:

251

10.1080/00222933.2015.1103910.

252

253

254

255

256

257

258

259

Childers CC, Easterbrook MG, Solomon MG. 1996. Chemical control of eriophyoid mites. In: Lindquist EE, Sabelis MW, Bruin J, eds. Eriophyoid mites: their biology, natural enemies and control. Amsterdam: Elsevier, 695-726 DOI: 10.1016/S1572-4379(96)80048-0.

Copping LG, Menn JJ. 2000. Biopesticides: a review of their action, applications and efficacy. Pest Management Science 56:651-676 DOI: 10.1002/1526-4998(200008)56:8<651::aidps201>3.0.co;2-u.

de Lillo E, Pozzebon A, Valenzano D, Duso C. 2018. An intimate relationship between eriophyoid mites and their host plants - a review. Frontiers in Plant Science 9:1-14 DOI: 
10.3389/fpls.2018.01786.

261 Duso C, Castagnoli M, Simoni S, Angeli G. 2010. The impact of eriophyoids on crops: recent

262 issues on Aculus schlechtendali, Calepitrimerus vitis and Aculops lycopersici. Experimental

263 and Applied Acarology 51:151-68 DOI: 10.1007/s10493-009-9300-0.

264 Eckstein R, Karlsson P, Weih M. 1998. The significance of resorption of leaf resources for shoot 265 growth in evergreen and deciduous woody plants from a subarctic environment. Oikos 81:569-577 DOI: $10.2307 / 3546777$.

267 Erbilgin N, Galvez DA, Zhang B, Najar A. 2014. Resource availability and repeated defoliation 268 mediate compensatory growth in trembling aspen (Populus tremuloides) seedlings. PeerJ 269 2:e491 DOI: $10.7717 /$ peerj.491.

270 Eyles A, Barry KM, Quentin A, Pinkard EA. 2013. Impact of defoliation in temperate eucalypt 271 plantations: physiological perspectives and management implications. Forest Ecology and Management 304:49-64 DOI: 10.1016/j.foreco.2013.04.033.

273 Faircloth JC, Edmisten KL, Wells R, Stewart AM. 2004. The influence of defoliation timing on 274 yields and quality of two cotton cultivars. Crop Science 44:165-172 DOI:

$275 \quad 10.2135 /$ cropsci2004.0165.

276 Guyot J, Omanda EN, Ndoutoume A, Otsaghe AAM, Enjalric F, Assoumou HGN. 2001. Effect 277 of controlling Colletotrichum leaf fall of rubber tree on epidemic development and rubber 278 production. Crop Protection 20:581-590 DOI: 10.1016/S0261-2194(01)00027-8.

279 Hrudová E, Šafránková I. 2017. Goji berry gall mite Aceria kuko occurrence in the Czech 280 Republic - short communication. Plant Protection Science 54:39-42 DOI:

$281 \quad$ 10.17221/14/2017-PPS.

282 Jetton RM, Robison DJ. 2014. Effects of artificial defoliation on growth and biomass 
accumulation in short-rotation sweetgum (Liquidambar styraciflua) in North Carolina. Journal of Insect Science 14:107 DOI: 10.1673/031.014.107.

Kosola KR, Dickmann DI, Paul EA, Parry D. 2001. Repeated insect defoliation effects on growth, nitrogen acquisition, carbohydrates, and root demography of poplars. Oecologia 129:65-74 DOI: 10.1007/s004420100694.

Krantz GW, Lindquist EE. 1979. Evolution of phytophagous mites (Acari). Annual Review of Entomology 24:121-158 Doi: 10.1146/annur ev.en.24.010179.001005.

Kulman HM. 1971. Effects of insect defoliation on growth and mortality of trees. Annual Review of Entomology 16:289-324 DOI: 10.1146/annurev.en.16.010171.001445.

Lasseur B, Lothier J, Morvan-Bertrand A, Escobar-Guttiérez A, Humphreys MO, Prud'homme

$$
\text { MP. 2007. Impact of defoliation frequency on regrowth and carbohydrate metabolism in }
$$

Lawal B. 2014. Applied statistical methods in agriculture, health and life sciences. Malete: Springer DOI: 10.1007/978-3-319-05555-8.

Lee SY, Morton B. 2003. Effects of artificial defoliation on growth, reproduction and leaf chemistry of the mangrove Kandelia candel. Journal of Tropical Ecology 19:397-406 DOI:

Li J, Liu S, Guo K, Zhang F, Qiao H, Chen J, Yang M, Zhu X, Xu R, Xu C, Chen J, 2018. Plantmediated competition facilitates a phoretic association between a gall mite and a psyllid vector. Experimental and Applied Acarology 76:325-337 DOI: 10.1007/s10493-018-0315-2.

Lindquist EE. 1996. External anatomy and notation of structures. In: Lindquist EE, Sabelis MW, Bruin J, eds. Eriophyoid Mites: their biology, natural enemies and control. Amsterdam: 
Elsevier, 3-31 DOI: 10.1016/S1572-4379(96)80003-0.

307 Lindquist EE, Oldfield GN. 1996. Evolution of eriophyoid mites in relation to their host plants.

308 In: Lindquist EE, Sabelis MW, Bruin J, eds. Eriophyoid Mites: their biology, natural

309 enemies and control. Amsterdam: Elsevier 277-300 DOI: 10.1016/S1572-4379(96)80018-2.

310 Liu S, Li J, Guo K, Qiao H, Xu R, Chen J, Xu C, Chen J. 2016. Seasonal phoresy as an

311 overwintering strategy of a phytophagous mite. Scientific Reports 6:25483 DOI:

$312 \quad 10.1038 /$ srep25483.

313 Mani M. 1964. Ecology of plant galls. Dordrech: Springer DOI: 10.1007/978-94-017-6230-4.

314 Marcic D. 2012. Acaricides in modern management of plant-feeding mites. Journal of Pest

315 Science 85:395-408 DOI: 10.1007/s10340-012-0442-1.

316 Michalska K, Skoracka A, Navia D, Amrine JW. 2010. Behavioural studies on eriophyoid mites:

317 an overview. Experimental and Applied Acarology 51:31-59 DOI: 10.1007/s10493-009-

$3189319-2$.

319 Milbrath LR. 2008. Growth and reproduction of invasive Vincetoxicum rossicum and $V$. nigrum

320 under artificial defoliation and different light environments. Botany 86:1279-1290 DOI:

$321 \quad$ 10.1139/B08-092.

322 Mo J, McDougall S, Beaumont S, Munro S, Stevens MM. 2018. Effects of simulated seedling

323 defoliation on growth and yield of cotton in southern New South Wales. Crop and Pasture

$324 \quad$ Science 69:915 DOI: 10.1071/CP18093.

325 Nakajima H. 2018. Refoliation of deciduous canopy trees following severe insect defoliation:

326 comparison of Fagus crenata and Quercus crispula. Plant Ecology 219:665-675 DOI:

$327 \quad 10.1007 / \mathrm{s} 1125$.

328 Navia D, Ochoa R, Welbourn C, Ferragut F. 2010. Adventive eriophyoid mites: a global review 
of their impact, pathways, prevention and challenges. Experimental and Applied Acarology 51:225-255 DOI: 10.1007/s10493-009-9327-2.

331 Oldfield GN, Michalska K. 1996. Spermatophore deposition, mating behavior and population mating structure. In: Lindquist EE, Sabelis MW, Bruin J, eds. Eriophyoid mites: their biology, natural enemies and control. Amsterdam: Elsevier, 185-198 DOI: 10.1016/S15724379(96)80010-8.

Oldfield GN, Proeseler G. 1996. Eriophyoid mites as vectors of plant pathogens. In: Lindquist EE, Sabelis MW, Bruin J, eds. Eriophyoid mites: their biology, natural enemies and control. Amsterdam: Elsevier, 259-275 DOI: 10.1016/S1572-4379(96)80017-0.

Price PW, Fernandes GW, Waring GL. 1987. Adaptive nature of insect galls. Environmental Entomology 16:15-24 DOI: 10.1093/ee/16.1.15.

Quentin AG, Pinkard EA, Beadle CL, Wardlaw TJ, O'Grady AP, Paterson S, Mohammed CL.

Rao BS. 1971. Avoiding secondary leaf fall disease of rubber by chemical defoliation. Pans Pest 2010. Do artificial and natural defoliation have similar effects on physiology of Eucalyptus globulus Labill. seedlings? Annals of Forest Science 67:203-203 DOI: Articles \& News Summaries 17:461-463 DOI: 10.1080/09670877109413316.

Reichenbacker R, Schultz R. Hart E. 1996. Artificial defoliation effect on Populus growth, 10.1051/forest/2009096.

Sabelis MW, Bruin J. 1996. Evolutionary ecology: life history patterns, food plant choice and dispersal. In: Lindquist EE, Sabelis MW, Bruin J. eds. Eriophyoid mites: their biology, natural enemies and control. Amsterdam. Elsevier, 329-366 DOI: 10.1016/S1572- 

4379(96)80020-0.

353 Stone GN, Schönrogge K. 2003. The adaptive significance of insect gall morphology. Trends 354 Ecol Evol 18: 512-522 DOI: 10.1016/S0169-5347(03)00247-7.

355 Van Leeuwen T, Tirry L, Yamamoto A, Nauen R, Dermauw W. 2014. The economic importance 356 of acaricides in the control of phytophagous mites and an update on recent acaricide mode of 357 action research. Pesticide Biochemistry and Physiology 121:12-21 DOI:

$358 \quad$ 10.1016/j.pestbp.2014.12.009.

359 Van Leeuwen T, Witters J, Nauen R, Duso C, Tirry L. 2010. The control of eriophyoid mites:

360 state of the art and future challenges. Experimental and Applied Acarology 51:225-255 DOI:

$361 \quad 10.1007 / \mathrm{s} 10493-009-9312-9$.

362 Walter DE, Proctor HC. 2013. Mites on Plants. In: Walter DE, Proctor HC. eds. Mites: Ecology, 363 Evolution \& Behaviour. Springer, Dordrecht: 281-339 DOI: 10.1007/978-94-007-7164-2_8.

364 Xu C, Liu S, Xu R, Chen J, Qiao H, Jin H, Lin C, Guo K, Cheng H. 2014. Investigation of 365 production status in major wolfberry producing areas of China and some suggestions. China 366 Journal of Chinese Materia Medica 39:1979-1984 DOI: 10. 4268 /cjcmm20141106.

367 Yao R, Heinrich M, Wang Z, Weckerle CS. 2018. Quality control of goji (fruits of Lycium 368 barbarum L. and L. chinense Mill.): a value chain analysis perspective. Journal of 369 Ethnopharmacology. 224:349-358 DOI: 10.1016/j.jep.2018.06.010. 


\section{Table 1 (on next page)}

Information and applied doses of defoliant and pesticides 


\begin{tabular}{|c|c|c|c|c|}
\hline Product & & Manufacturer & $\begin{array}{l}\text { Active ingredient concentration } \\
\text { and formulation }\end{array}$ & $\begin{array}{l}\text { Applied doses } \\
(\mathrm{mg} \mathrm{AI} / \mathrm{kg})\end{array}$ \\
\hline Defoliant & Dropp ultra ${ }^{\circledR}$ & Bayer Crop Science, Leverkusen, Germany & $\begin{array}{l}540 \mathrm{~g} / \mathrm{L}(360 \mathrm{~g} / \mathrm{L} \text { diuron and } 180 \\
\mathrm{g} / \mathrm{L} \text { thidiazuron) suspension } \\
\text { concentrate }\end{array}$ & 72 \\
\hline \multirow{8}{*}{ Pesticides } & Abamectin & $\begin{array}{l}\text { North China Pharmaceutical Group Aino Co., Ltd, } \\
\text { Shijiazhuang, China }\end{array}$ & $1.8 \%$ emulsifiable concentrate & 15 \\
\hline & Imidacloprid & Bayer Crop Science, Leverkusen, Germany & $200 \mathrm{~g} / \mathrm{L}$ soluble concentrate & 100 \\
\hline & Chlorpyriphos & Dow AgroSciences, Indianapolis, USA & $40 \%$ emulsion in water & 400 \\
\hline & Acetamiprid & $\begin{array}{l}\text { Hebei Weiyuan Biological and Chemical Co., Ltd., } \\
\text { Shijiazhuang, China }\end{array}$ & $20 \%$ soluble concentrate & 40 \\
\hline & Spinetoram & Dow AgroSciences, Indianapolis, USA & $60 \mathrm{~g} / \mathrm{L}$ suspension concentrate & 30 \\
\hline & Sulphur & Hebei Shuangji Chemicals Co. Ltd., Xinji, China & $50 \%$ suspension concentrate & 1000 \\
\hline & Azadirachtin & Chengdu Green Gold Hi-Tech Co., Ltd., Chengdu, China & $0.3 \%$ emulsifiable concentrate & 6 \\
\hline & Matrine & Jiangsu Fengshan Group Co., Ltd., Yancheng, China & $0.3 \%$ soluble concentrate & 6 \\
\hline
\end{tabular}


Table 2 (on next page)

Application information for the defoliant and pesticides from 2012 to 2014 


\begin{tabular}{|c|c|c|}
\hline Treatment & Application time & Ingredient \\
\hline \multirow{3}{*}{ Defoliant } & 2012 23-Jul & \multirow{3}{*}{ Dropp ultra ${ }^{\circledR}$} \\
\hline & 12-Jul & \\
\hline & 2014 20-Jul & \\
\hline \multirow{9}{*}{ Pesticides } & 2-Aug & Abamectin + chlorpyriphos \\
\hline & 4-Sep & Abamectin + acetamiprid + imidacloprid \\
\hline & \multirow{4}{*}{$\begin{array}{l}\text { 12-Jul } \\
\text { 24-Jul } \\
\text { 26-Aug } \\
\text { 5-Sep }\end{array}$} & Abamectin + chlorpyriphos \\
\hline & & Abamectin + chlorpyriphos + imidacloprid \\
\hline & & Abamectin + chlorpyriphos \\
\hline & & Abamectin + acetamiprid \\
\hline & 20-Jul & Spinetoram + azadirachtin \\
\hline & 1-Aug & Spinetoram + azadirachtin + sulphur \\
\hline & 12-Aug & Azadirachtin + matrine + sulphur \\
\hline
\end{tabular}




\section{Table 3 (on next page)}

Number of $(A)$ old and $(B)$ new foliage per branch in the defoliant treatment and pesticide treatment after defoliant application in 2012

Five replications were performed for each treatment, and 2 bushes were selected in each

replication. Error bars are \pm SD. *, ** and *** indicate significant differences between the defoliant and pesticide treatments on the same day, i.e., $P<0.05,0.01$ and 0.001 , respectively. ns indicates no significant differences on the same day, i.e., $P>0.05$ 


\begin{tabular}{lllllll}
\hline \multirow{2}{*}{ Source } & Treatment & \multicolumn{6}{l}{ Days after defoliant application } \\
\cline { 3 - 7 } & & $\mathbf{0}$ & $\mathbf{1}$ & $\mathbf{3}$ & $\mathbf{7}$ & $\mathbf{1 3}$ \\
\hline \multirow{2}{*}{ Old foliage } & Defoliant & $35.5 \pm 3.92$ & $20.2 \pm 4.83$ & $2.0 \pm 1.30$ & $1.0 \pm 0.63$ & 0 \\
& Pesticides & $31.2 \pm 3.73^{\text {ns }}$ & $32.1 \pm 3.59^{* *}$ & $27.9 \pm 1.18^{* * *}$ & $23.2 \pm 2.96^{* * *}$ & $18.2 \pm 1.72^{* * *}$ \\
\multirow{2}{*}{ New foliage } & Defoliant & 0 & 0 & 0 & $5.3 \pm 2.71^{*}$ & $72.9 \pm 10.29^{* * *}$ \\
& Pesticides & 0 & 0 & 0 & 0 & $2.1 \pm 1.44$ \\
\hline
\end{tabular}


Table 4 (on next page)

Results of the analyses of gall dynamics in which comparisons of the number of galls were performed for dates, treatments and their interaction over 3 years of experimentation

Five replications were performed for each treatment, and 2 bushes were selected in each replication 


\begin{tabular}{llllll}
\hline Year & Source & df & Mean square & $\boldsymbol{F}$ & P-value \\
\hline \multirow{2}{*}{2012} & Date & 8 & 586.230 & 11.616 & $<0.001$ \\
& Treatment & 1 & 1717.498 & 43.917 & $<0.001$ \\
& Date $\times$ Treatment & 8 & 508.422 & 10.074 & $<0.001$ \\
\hline \multirow{2}{*}{2013} & Date & 7 & 242.973 & 1.098 & 0.348 \\
& Treatment & 1 & 1216.956 & 19.969 & 0.002 \\
& Date $\times$ Treatment & 7 & 193.424 & 0.874 & 0.416 \\
\hline \multirow{2}{*}{2014} & Date & 8 & 399.217 & 3.876 & 0.048 \\
& Treatment & 1 & 883.475 & 14.673 & 0.005 \\
& Date $\times$ Treatment & 8 & 421.947 & 4.097 & 0.042 \\
\hline
\end{tabular}


Figure 1

(A) Galls induced by $A$. pallida on leaf; and (B) adult $A$. pallida under an electron microscope 


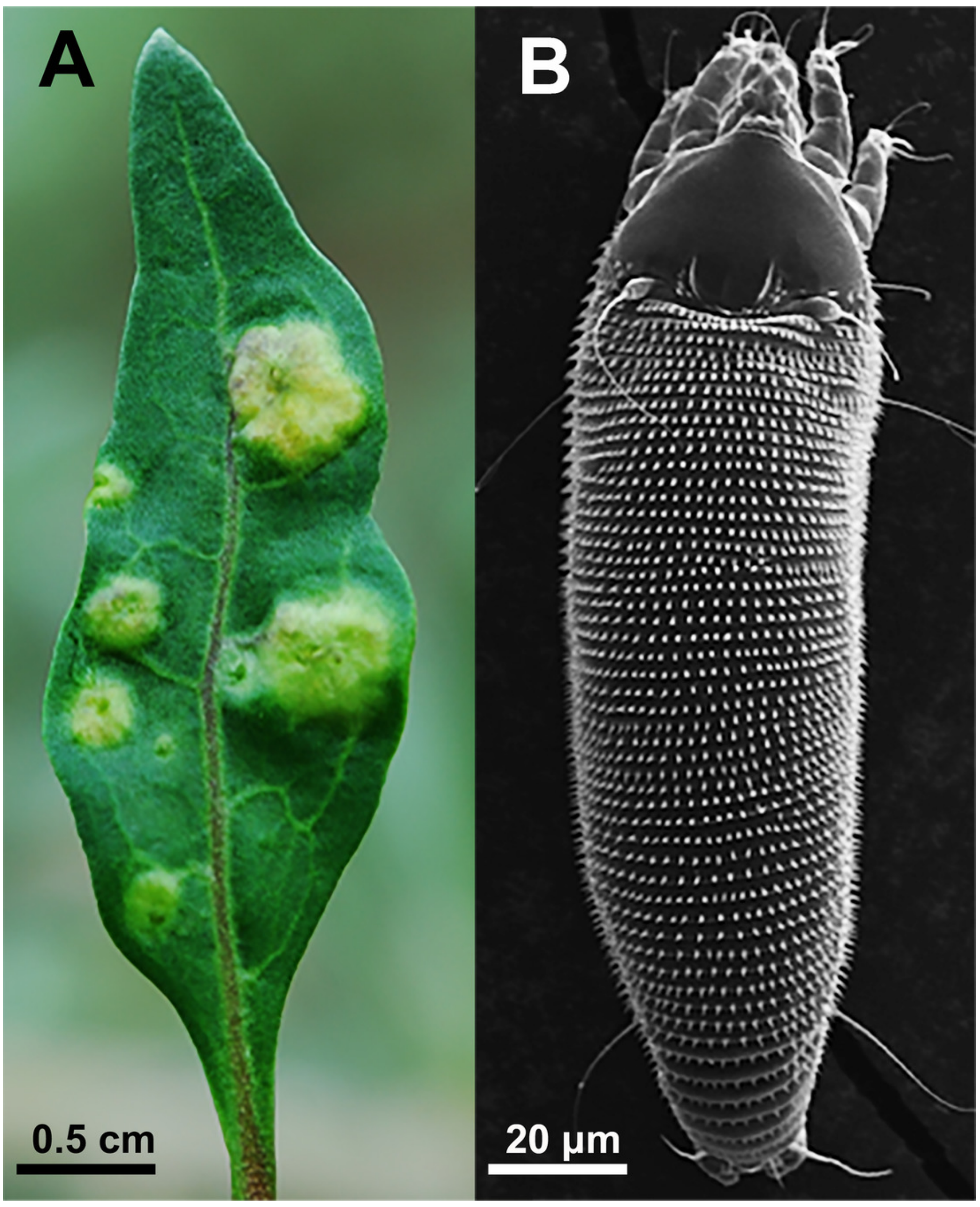




\section{Figure 2}

Dynamics of galls in the defoliant treatment and pesticide treatment in (A) 2012, (B) 2013 and (C) 2014. Number of galls per branch per day in (D) 2012, (E) 2013 and (F) 2014

Black arrows indicate the time of defoliant application and white arrows indicate the time of pesticide application. Five replications were performed for each treatment, and 2 bushes were selected in each replication. Error bars are \pm SE. ${ }^{* *}$ and $* * *$ indicate significant differences between the defoliant and pesticide treatments, i.e., $P<0.01$ and 0.001 , respectively 

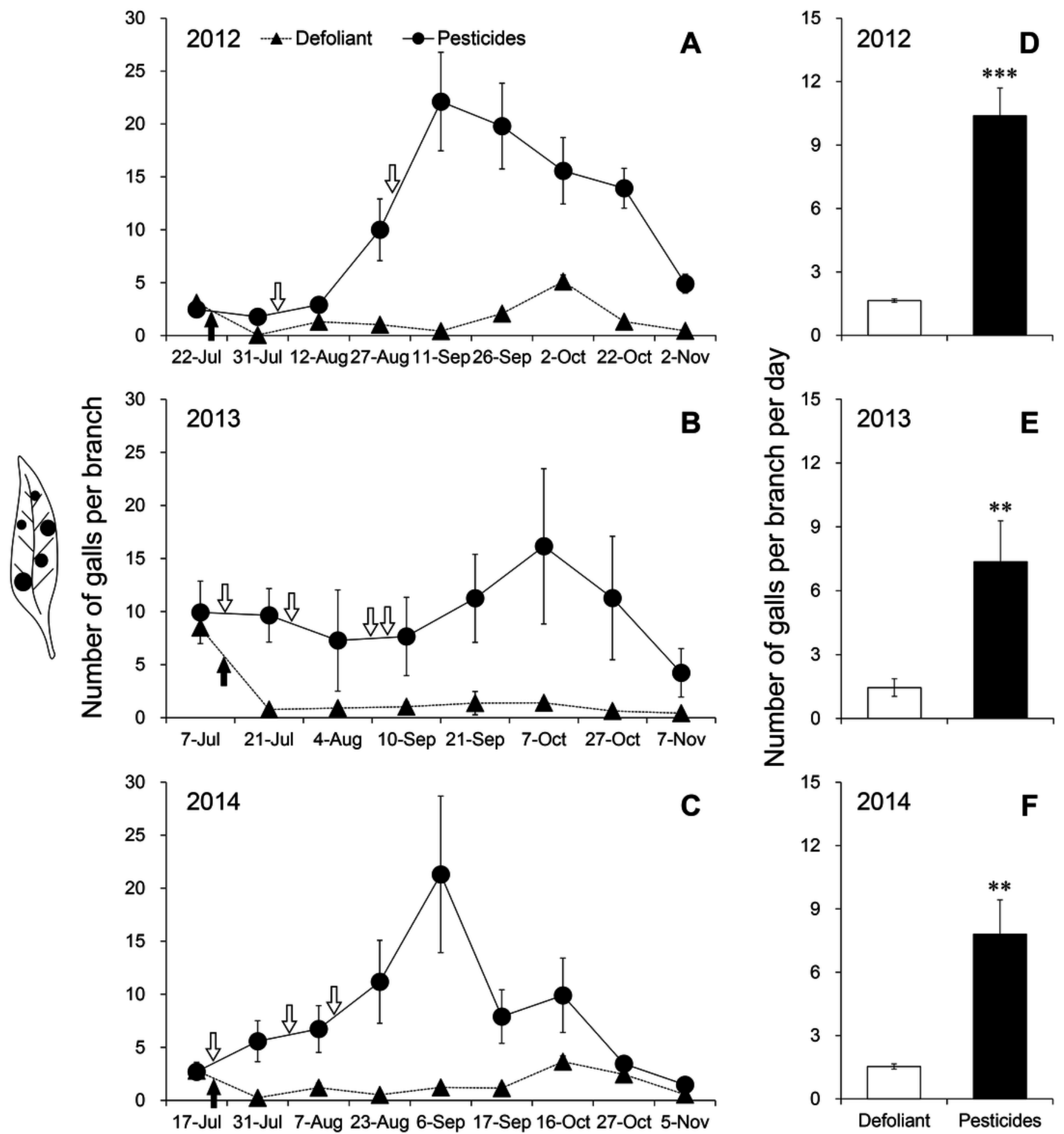